\title{
Sedum pallidum (Crassulaceae) - alien species of the flora of plain part of Ukraine
}

\author{
O.I. Shynder *, Y.M. Negrash \\ M.M. Gryshko National Botanical Garden, National Academy of Sciences of Ukraine, Timiryazyevska str. 1, 01014 Kyiv, Ukraine; \\ * shinderoleksandr@gmail.com
}

Received: 18.02 .2020 | Accepted: 03.05.2020 | Published: 30.06 .2020

\begin{abstract}
The objective of this study was to evaluate the current distribution of Sedum pallidum in Ukraine, to analyze its state in the alien flora of Ukraine.

Material and methods. The studies were conducted in 2008-2019 in the plain part of Ukraine and the Crimean Mountains. Literature information, several national herbarium collections, and other sources were analyzed. Special attention was paid to the delimitation of synanthropic locations of S. pallidum from cultural ones.

Results. S. pallidum is a sub-euxine species, which range occupies the Crimean Mountains. It is widely cultivated throughout Ukraine and is prone to naturalization, thanks to its vegetative and generative reproduction. In general, about 30 synanthropic locations of S. pallidum have been recorded, mainly in the Middle Prydniprovia and Western Ukraine. Urban lawns and roadsides on light substrates are favorable ecological niches for S. pallidum.

Conclusions. S. pallidum is the alien species in the flora of the plain part of Ukraine and ergasiophyte in its origin. A potential secondary synanthropic range of this species occupies the whole country except the Carpathian highlands. It has been established that S. pallidum in the culture of the Forest-Steppe is a perennial herb. Two races identified in its composition (var. pallidum and var. bithynicum) are probably ecads and have no systematic importance. In the culture, S. pallidum is characterized by successful vegetative and generative reproduction, which contributes to its naturalization. S. pallidum is often confused with other species of the genus, which does not contribute to its study in adventive floras. A key for S. pallidum determination has been proposed.
\end{abstract}

\section{Introduction}

The timely detection of new alien plant species is a contemporary pressing issue. During the acclimatization and naturalization, many alien plant species escape beyond the places of cultivation and replenish synanthropic flora. The number of escaped plants has increased rapidly in recent decades, causing modern concerns (Protopopova \& Shevera, 2012, 2013;
Shynder, 2019b). The family Crassulaceae J. St.Hil. is characterized by the great diversity of cultivated species. Many species of the family naturalize and form secondary synanthropic ranges (Byalt, 2011). Sedum pallidum M. Bieb belongs to such species, widely handled as an ornamental plant throughout the plain part of Ukraine and is prone to naturalization. There is no reliable information about the naturalization of S. pallidum in Ukraine, so the 


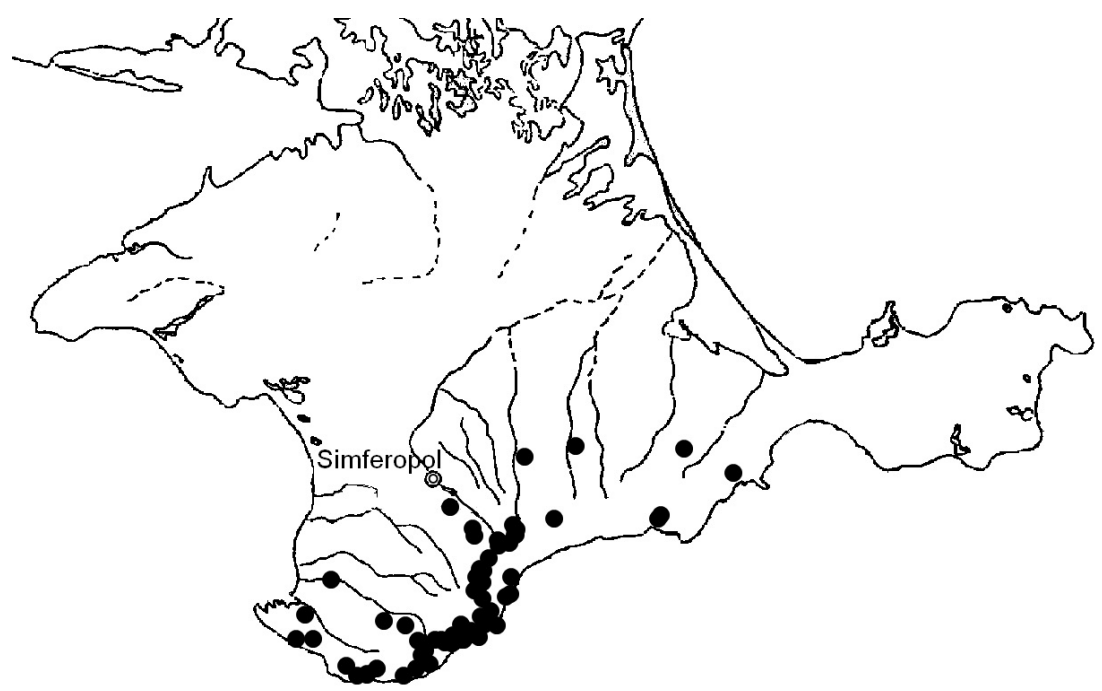

Figure 1. Natural locations of Sedum pallidum on the Crimean peninsula.

establishment of a synanthropic range of this species is relevant. Hence, the objective of this study was to clarify the current distribution of S. pallidum in Ukraine and to analyze its state in the alien flora of Ukraine.

\section{Material and methods}

The floristic and comparative-morphological studies of $S$. pallidum in the natural, introduction, and synanthropic habitats were conducted in 2008-2019 in the plain part of Ukraine and the Crimean Mountains. Some plants were introduced to the M.M. Gryshko National Botanical Garden of the National Academy of Sciences of Ukraine for further exact determination. Herbariums of KW, KWHA, KWU, LWS, and LWKS (see Index Herbariorum (Thiers, 2020) for abbreviations), literature and other sources were analyzed to summarize the chorological information (Wulf, 1960; Shynder et al., 2018; Shynder, 2019b; UkrBIN, 2020).

Classification of groups of alien plants is provided with respect to published sources (Protopopova \& Shevera, 2012; Shynder, 2019a). An important task was the separation of the synanthropic habitats of S. pallidum from the places of its cultivation. As we showed before (Shynder, 2019a), artificially planted plants after abandoning care of them (so-called "relicts of culture") should not be attributed to spontaneous habitats. Sometimes plantations of S. pallidum sprawl and form a carpet cover over a large area, which is similar to the spontaneous population, and the flowerbed itself may not exist. But the cultural origin of such colonies can be identified by the remains of old beds and other representatives of the cultural flora. As synanthropic (adventitious), we refer to those populations, which were located at some distance from flowerbeds and composed of many individuals and their groups, often covering a large area (sometimes several dozens of ares).

\section{Results and discussion}

Sedum pallidum is a sub-euxine species with a range covering the Crimean Mountains, the southeastern part of the Balkan Peninsula, Asia Minor, the South Caucasus, North-Western Iran and Cyprus (Wulf, 1960; Chamberlain \& Muirhead, 1972; Byalt, 2001; Hart \& Eggli, 2003). In the Crimean Mountains, S. pallidum is at the northern limit of its natural range. Here, according to herbariums data, literature sources (Wulf, 1960), and our own field observations, we have identified 70 locations of the species that outline the Crimean part of its range (Fig. 1). Most of the Crimean locations of S. pallidum are concentrated in the western part of the main mountain range. In other parts of the Crimean Mountains, the species occurs only sporadically.

The natural habitats of S. pallidum are attributed to rocky substrates with moderate moisture - rocks, scree, and sometimes occur in light forests. Comparing with the 


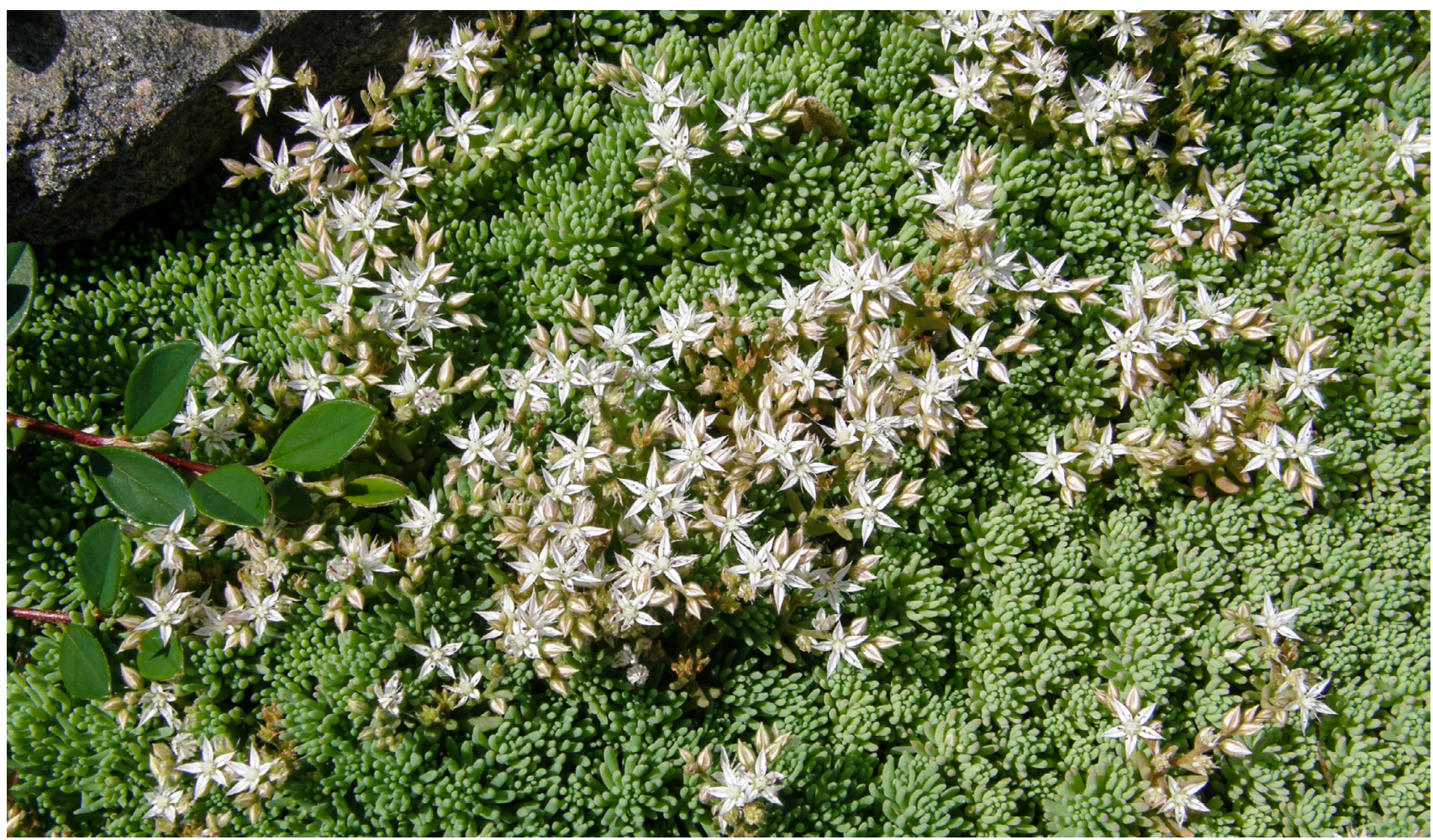

Figure 2. Sedum pallidum of Crimean origin in culture in Kyiv.

close species S. hispanicum L., the habitats of S. pallidum are moister (Wulf, 1960; Byalt, 2001). The species is widely cultivated in many countries of the Holarctic as a ground-covering perennial plant and is prone to naturalization. S. pallidum often occurs wild in Southern Scandinavia and Central Europe (Byalt, 2011; Bomble \& Wolgarten, 2012; Hohla, 2018). In Eastern Europe, this species sometimes escapes beyond the places of cultivation (Byalt, 2001). It is also naturalized in China and Japan (Byalt, 2011). Probably one of the adaptations of $\mathrm{S}$. pallidum to the successful growth in conditions of high humidity is guttation. In the condition of Kyiv, guttation in S. pallidum is quite pronounced in comparison with other species of the family. It happens even when it is not observed in other species.

The biomorphological characteristics of the species differ among published sources. Wulf (1960) attributed S. pallidum to annuals and biennials. A number of authors distinguish two biomorphological races within S. pallidum s.l.: a) the annual typical var. pallidum (= subsp. pallidum) with or without few shoots, which are never wintering; b) the perennial var. bithynicum (Boiss.) D.F. Chamb. (= subsp. bithynicum (Boiss.) V.V. Byalt) with numerous sterile wintering shoots. Only annual plants are described for the Crimean Mountains
(Chamberlain \& Muirhead, 1972; Byalt, 2001). Byalt (2001) attributed S. pallidum to annuals or biennials. He described both races as cultivated plants in Eastern Europe and noted that subsp. bithynicum is cultivated more often. Hart \& Eggli (2003) placed S. bithynicum in synonyms to S. pallidum and characterized the species as perennial. The authors also noted that all sterile shoots could periodically form inflorescences, and in this case, the plants become monocarpic.

We tend to regard $S$. pallidum as a vegetatively mobile herbaceous perennial that forms monocarpic generative shoots and is prone to particulation. In 2007 and 2008 we introduced living plants of S. pallidum from different locations of Crimean yaylas to the M.M. Gryshko National Botanical Garden NAS of Ukraine. All plants have taken roots well and for several years have formed a thick carpet in which sterile wintering shoots prevailed numerically; in the following year, some of them have formed generative shoots (Fig. 2). Generative shoots wither after flowering, often together with nodes of tillering (especially in the conditions of drought). This fact leads to the particulation of the maternal individual. However, in the situation of sufficient moisture, the lower part of the withered stems can persist and become a short-lived rhizome. 
Probably, in conditions of dry habitats of the Crimean Mountains, plants could not always be able to form a sufficient number of sterile shoots. In Crimean habitats that we observed, S. pallidum plants formed mainly generative shoots and were not prone to intense vegetative overgrowth. Thus, the plants of S. pallidum from the Crimean geographical population are only facultative annuals, if they are at all. Hence, the races identified within S. pallidum are not independent taxonomic units but simply ecads.

In the conditions of Kyiv, cultivated plants successfully produced self-seeding. Seedlings appear in September and October, and the rosette size increases before winter. Thus, in the Forest-Steppe conditions, S. pallidum is characterized by successful vegetative and generative reproduction. The rapid vegetative sprawl and attractive greenish-glaucous color of the vegetative parts contributed to the popularity of S. pallidum for the landscape of the large areas, primarily for municipal sites. In places of cultivation, S. pallidum is characterized by durability and often extends on adjacent areas, where it successfully anchors.

Despite the fact that S. pallidum has become a trivial species in urban landscapes, it was not usually cited in the lists of the alien flora of cities and regions of Ukraine until recently. However, after the revision of herbariums and published material, it was found that S. pallidum was sometimes reported, but under other names (Kagalo et al., 2004; Kuzyarin, 2012; Doyko \& Katrevych, 2015).

The list of secondary synanthropic locations of S. pallidum in the plain part of Ukraine is given in the Appendix.

Also, we have repeatedly registered persistent colonies of cultural origin near abandoned or existing places of S. pallidum cultivation and flowerbeds. For example, we noted such colonies in Rudnytsia (Vinnytsia region), Rzhyshchiv (Kyiv region), Kaniv, Smila, Talne, and Uman (Cherkasy region, in all cases in parks), Dzhankoy (Crimea). It should be noted that the locations of S. pallidum, obviously of introduction origin, were also found in the seaside part of the Southern coast of Crimea (according to O.F. Levon). Still, the secondary range of this species can be separated from the natural one only in the Steppe Crimea.
Thus, nowadays, there are about 30 synanthropic locations of S. pallidum, most of which are recorded from the Middle Prydniprovia and Western Ukraine (Fig. 3). Urban lawns and roadsides on sandy and other light substrates are the favorable ecological niches for S. pallidum. Their regular mowing promotes the vegetative dispersal of the species (especially in regions with sufficient moisture) and eliminates competition from tall herbaceous plants. The most of synanthropic S. pallidum locations were recorded in similar habitats, where the species was at the stage of the beginning of an expansion. In some other ecotopes, for example, on railway embankments, sandy roadsides of forest roads, around the edges of forests, S. pallidum was rarely recorded and was only at the stage of initial expansion and fixing. In all the cases, curtains and colonies of S. pallidum developed successfully on wellaerated substrates.

Today, there is every reason to believe that S. pallidum participates in floras of all large and many medium-sized cities of Ukraine as an adventitious element. So, the potential secondary synanthropic range of this species covers the whole Ukraine with except the Carpathian highlands. But outside of urbanized landscapes, not all areas of Ukraine can be suitable for S. pallidum naturalization. For example, in the southern lane of the Rightbank Forest-Steppe, S. pallidum occurs in a culture quite rarely, and we have not noticed any of its synanthropic habitat. The rarity of S. pallidum in the culture of this terrain is explained by the absence of large cities and the prevalence of traditional landscaping methods on agrarian areas (without rockeries and carpet flowerbeds). In addition, the ecological conditions of the southern strip of the ForestSteppe (with soils of heavy texture, lack of atmospheric moisture, frequent dominance of turfy steppe and tall adventive plant species in ruderal ecotopes), probably much less favorable for S. pallidum naturalization comparing to the northern strip of the Middle Prydniprovia and Western Ukraine.

Thus, S. pallidum is an ergasiophyte in its origin, which in current conditions, became a part of the adventive flora of Ukraine. The first synanthropic finding of this species dates to 2001, so according to the time of immigration, it is eukenophyte - alien 


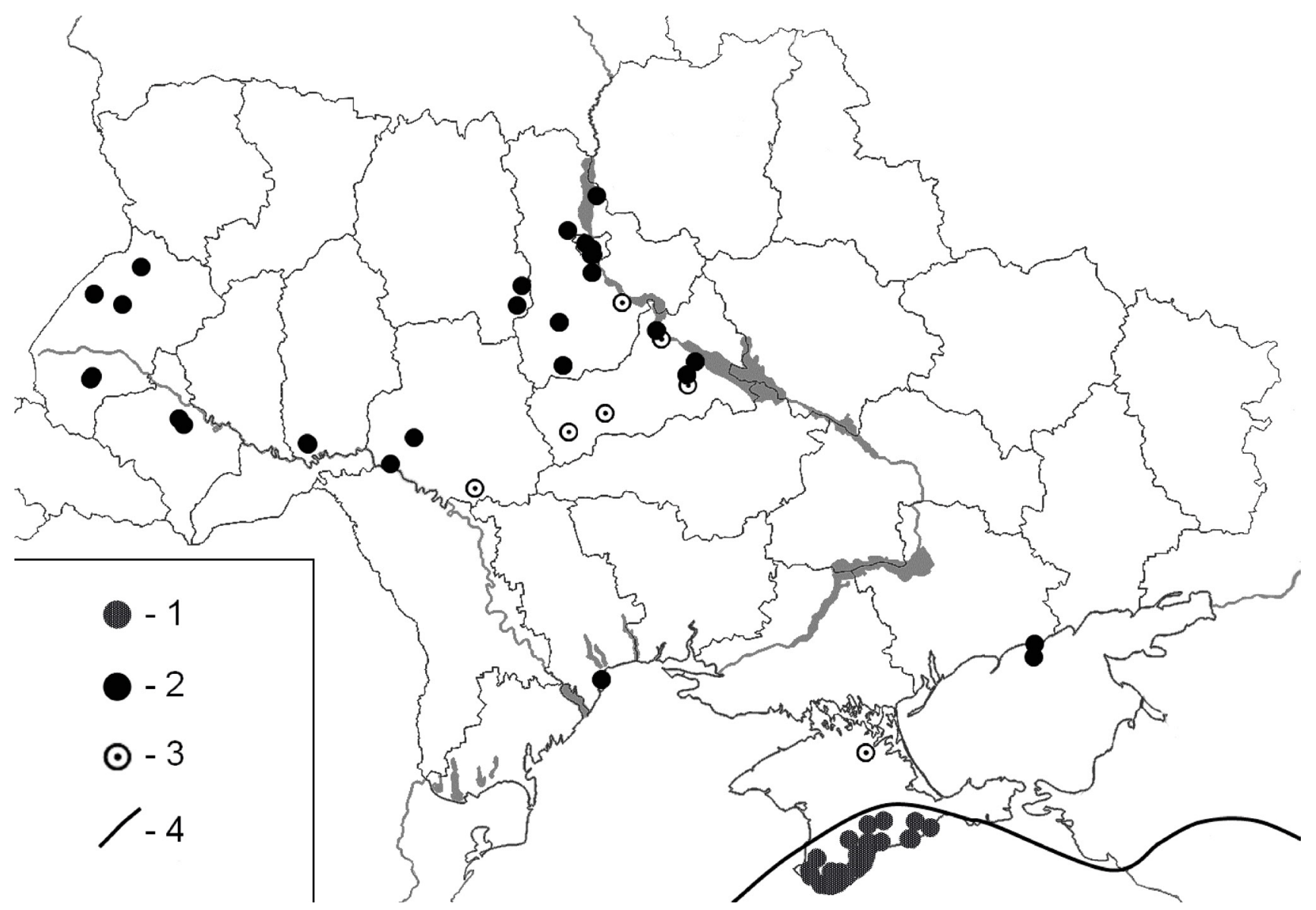

Figure 3. The modern distribution of Sedum pallidum in Ukraine. 1 - natural localities, 2 - synanthropic localities, 3 - populations-colonies in places of cultivation, 4 - the northern boundary of the primary range.

species that has come since the end of the XX century (Protopopova \& Shevera, 2012). In synanthropic habitats, by the degree of naturalization, S. pallidum participates as a typical colonophyte (species that form stable local populations in synanthropic habitats). In some urban floras, such as floras of Kyiv and Lviv, it demonstrates a tendency to expand further and gradually goes into a group of epekophytes (species that have fully naturalized in anthropogenic habitats). At the moment, S. pallidum should be considered as an unstable element of flora. But, in some urban areas, this species is already sufficiently entrenched in many secondary ecotopes and is a potentially expansive species. Due to its current distribution and ecological features, S. pallidum can be widely spread in the ruderal and semi-natural ecotopes of Polissya and Western Ukraine in the future. In more arid regions with fertile soils (Chernozems), its distribution will probably remain localized and will correlate with urban areas.

To clarify the species composition of the regional adventive floras, florists should pay attention to $\mathrm{S}$. pallidum. In many cases, it is also necessary to check the correctness of determination of Sedum specimens preserved in collections. As noted above, this species was widely represented as the escaped plant in our flora, but often misidentified with S. album, S. hispanicum, and S. lydium. After acquaintance with many private and scientific collections in Ukraine, we concluded that S. pallidum is one of the most common species representing the genus Sedum. Still, it is mostly unnamed, or it is provided under wrong names in such collections. S. pallidum is officially listed only for two collections of arboretums and botanical gardens, while S. lydium is mentioned for seven collections (Mashkovska, 2015). Taking into account that we have never (!) met living plants of S. lydium (at least in the flowering stage), we can assume that it is a result of numerous misidentifications.

Identification of Sedum s.l. can be problematic. Thus, the Asian S. lydium is mostly not included in published floras and identification keys in Europe. Byalt (2001) attributes S. pallidum to annuals or biennials, 

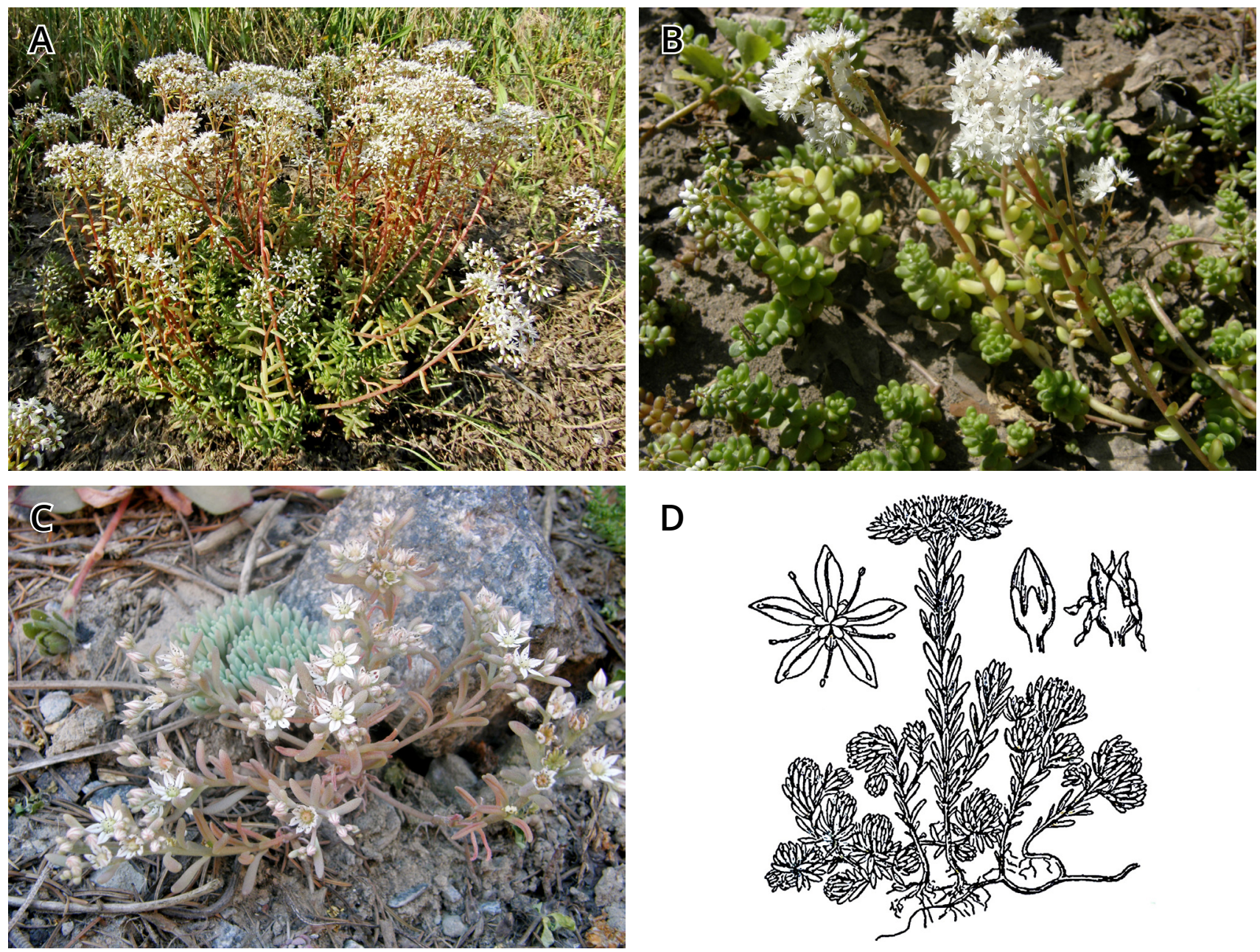

Figure 4. Low-growing white-flowering species of the genus Sedum: A - S. album, B - S. album 'Chloroticum', C - S. hispanicum, D - S. Iydium. Illustration of S. Iydium taken from Praeger (1921).

which sometimes also lead to doubts during identification. As noted above, in the ecologic conditions of the plains part of Ukraine, S. pallidum develops as a perennial plant. Since S. pallidum has so far been confused with S. album, S. hispanicum, and S. lydium, we outlined the main features distinguishing these species (Fig. 4).

The key for identification of Sedum pallidum and frequently confusing species in the flora of Ukraine

1. Plants annuals, glandular-pubescent; there are no sterile shoots, or they are single and are not rooted, flowers (5)6-7(9)-merous; in culture is rare S. hispanicum -. Plants with numerous sterile shoots that are rooted; flowers 5-merous 2

2. Plants bright-greenish-glaucous, sometimes with anthocyanin lower leaves; flowering stems low, glandular-pubescent; inflorescence is branching at the level of sterile shoots, diffuse, consist from several branches which diverge; widespread ........................ S. pallidum -. Plants dark-green or green (not glaucous), often burgundy or, rarely, with red lower leaves; flowering stems high rise above sterile shoots; inflorescences compact, rounded; plants completely glabrous 3

3. Turfs loose; sterile shoots of various lengths; plants dark-green, often burgundy; inflorescences of 20-50 flowers, loose; petals 3-4 times longer than sepals; widespread .................. S. album -. Turfs dense; plants green, but the lower leaves are often red, or the tips of the leaves are red; inflorescences of 5-20 flowers, dense, petals 1.5-2 times longer than sepals ....................... S. lydium 
During the flowering period, distinguishing these species is generally not a problem. In general, $\mathrm{S}$. pallidum is a widespread ground-covering plant that forms light greenish-glaucous curtains, sometimes with anthocyanin (purple) spots, and inflorescences are always glandular-pubescent. S. hispanicum is a glaucous-green, often with a gray and anthocyanin-burgundy tinge; it is a glandularpubescent annual plant, which does not sprawl, and is rare in collections. S. album is a widespread perennial that forms dark green carpets, often with a burgundy tinge (or entirely burgundy, but not purple). S. lydium is close to the S. album, and is characterized by dense, brighter green curtains and often red lower leaves or reddish tips on the upper leaves. Researchers should pay attention to that S. album and S. lydium are entirely glabrous plants. Distribution of S. lydium in culture in Ukraine requires further critical study. According to literature sources, this is a rather widespread species in culture (Byalt, 2001; Mashkovska, 2015), but those sedums that we have observed in private collections under identifications of S. lydium and S. lydium 'Glaucum' were found belonging to S. pallidum.

\section{Conclusions}

Sedum pallidum is an alien species and an unstable element of the flora of the plain part of Ukraine, an ergasiophyte in its origin. It is widely spread in the culture throughout the country. It has been established that S. pallidum in a culture of the Forest-Steppe is a perennial herb, and two races identified in its composition (var. pallidum and var. bithynicum) are probably ecads, which are out of systematic importance. In the culture, S. pallidum is characterized by successful vegetative and generative reproduction, which significantly supports its naturalization. In the urban floras of Kyiv and Lviv, this species tends to expand and becomes an epekophyte, but in most other regions, it is at the stage of colonophyte. In collections and floristic lists, the name S. pallidum is widely wrong adduced, which leads to confusion. Hence, we developed the key for the identification of S. pallidum. The potential secondary synanthropic range of this species occupies the whole country except the Carpathian highlands.

\section{References}

Bomble, F. W., \& Wolgarten, H. (2012). Die Bleiche Fetthenne (Sedum pallidum M. Bieb.) im Aachener Raum. Veröffentlichungen des Bochumer Botanischen Vereins, 4(5), 44-49.

Byalt, V. V. (2001). Crassulaceae. In N. N. Tzvelev (Ed.), Flora of Eastern Europe. Vol. 10 (pp. 250-285). St. Petersburg: Mir i Sem'ya.(In Russian)

Byalt, V. V. (2011). The adventive species in the Crassulaceae family. Russian Journal of Biological Invasions, 2, 28-34. https://doi.org/10.1134/ S2075111711030039

Chamberlain, D. F., \& Muirhead, C. W. (1972). Sedum L. In P. H. Davis (Ed.), Flora of Turkey and the East Aegean Islands. Vol. 4 (pp. 224-244). Edinburgh: Edinburgh University Press.

Doyko, N. M., \& Katrevych, M. V. (2015, September 15-17). Herbaceous ergasophyophytes in the Alexandria Arboretum. In Materials of the scientific conference "Plant introduction, biodiversity conservation and enrichment in botanical gardens and arboretums" (pp. 76-77). Kyiv. (In Ukrainian)

Hart, H.'t., \& Eggli, U. (2003). Sedums of Europe stonecrops and wallpeppers. London: CRC Press.

Hohla, M. (2018). Physalis grisea und Sedum pallidum neu für Österreich sowie weitere Beiträge zur Adventivflora von Österreich. Stapfia, 109, 25-40.

Kagalo, A. A., Skibitka, N. V., Lyubinskaya, L. G., Huzik Y., Protopopova, V. V., \& Shevera, M. V. (2004). Vascular plants of Kamianets-Podilskyi. In O. O. Kagalo, M. V. Shevera, \& A. A. Levanec (Eds.), Biodiversity of Kamianets-Podilskyi. Preliminary inventory conspectus of plants, mushrooms and animals (pp. 82-134). Lviv: Liga Press. (In Ukrainian)

Kuzyarin, A. T. (2012). New adventive species of vascular plants for Lviv region. Proceedings of the State Natural History Museum, 28, 143-144. (In Ukrainian)

Mashkovska, S. P. (Ed.). (2015). Catalog of ornamental herbaceous plants of botanical gardens and arboretums of Ukraine. Electronic Edition. Kyiv. (In Ukrainian)

Praeger, R. L. (1921). An account of the genus Sedum as found in cultivation. Journal of the Royal Horticultural Society, 46, 1-314. Retrieved from https://www.biodiversitylibrary.org/ bibliography/24520\#/summary

Protopopova, V. V., \& Shevera, M. V. (2012). Phytoinvasions II. Analysis of the main classifications, schemes and models. Industrial Botany, 12, 88-95. (In Ukrainian) 
Protopopova, V. V., \& Shevera, M. V. (2013, May 2831). Ergasiophigophytes in the flora of Ukraine: The present state and degree of development. In The role of botanical gardens and arboretums in preserving and enriching the biodiversity of urbanized territories (pp. 138-139). Kyiv. (In Ukrainian)

Shynder, O. I., (2019 a). Spontaneous flora of M.M. Gryshko National Botanical Garden of the NAS of Ukraine (Kyiv). 2. Methodological problems and criteria for selection of escaped plants in botanical garden conditions. Plant Introduction, 82, 3-16. (In Ukrainian). https://doi. org/10.5281/zenodo.3240995

Shynder, O. I., (2019 b). Spontaneous flora of M.M. Gryshko National Botanical Garden of the NAS of Ukraine (Kyiv). 3. Escaped plants. Plant Introduction, 83, 14-36. (In Ukrainian). https://doi. org/10.5281/zenodo.3404102
Shynder, O. I., Hlukhova, S. A., \& Mykhaylyk, S. M. (2018). Spontaneous flora of the Syrets Arboretum (Kyiv). Plant Introduction, 78, 5463. (In Ukrainian). https://doi.org/10.5281/ zenodo.2229967

Thiers, B. (2020). Index Herbariorum: A global directory of public herbaria and associated staff. Retrieved from http://sweetgum.nybg.org/science/ih/

UkrBIN. (2020, Jabuary 30). Sedum pallidum M. Bieb. UkrBIN (Ukrainian Biodiversity Information Network). Retrieved from http://ukrbin.com/ index. php?id=45092

Wulf, E. V. (1960). Flora of Crimea. Vol. 2, Issue 2. Moscow: Selkhozgiz. (In Russian)

Appendix. The list of secondary synanthropic (adventitious) locations of Sedum pallidum in the plains part of Ukraine. The sign "!!" indicates the findings of O.I. Shynder, "f.r." means field record, and "ph.m." photographic materials.

POLISSYA. Kyiv: Syretskiy Arboretum: open areas, wildly (Shynder et al., 2018); Kyiv region: Borodyanka district: Lubyanka - sporadically along the street, solitary curtains 09.05.2018 !!, f.r.; Vyshgorod district: the suburban district "Rovzhy", wildly, often along the roads, 18.10.2012 !!, f.r.

BROAD-LEAVED FORESTS ZONE. Lviv region: Lviv: lawn, in front of the central building of UNFU, wildly, 4.10.2019 !! (KWHA); Park "Pogulyanka" - on the roadside meadows, 30.05.2017 !! (KWHA). Sokal district: Sosnivka - the northern vicinities, in the composition of ruderal communities in railway embankments, 11.08.2011, A.T. Kuzyarin, sub S. lydium Boiss. - D. 15.10.2019, O.I. Shynder (LWS 116346) (Kuzyarin, 2012). Yavoriv district: in the vicinity of Novyi Yar, 49.957518, 23.506112, 2017, G. Golovko, Image ID \# 45725 (UkrBIN, 2020). Khmelnytsky region: Kamianets-Podilskyi: between slabs on the square near the city council, 07.08.2001, N.V. Skybitska, sub S. album. - D. 30.05.2017, O.I. Shynder (LWKS 004269/17767); the same, sub S. album (Kagalo et al., 2004); KamianetsPodilskyi: old town, walls near the fortress, on the lawns, etc., 26.07.2019 !!, O.I. Shynder, Yu.M. Negrash, f.r.

FOREST-STEPPE. Vinnytsia region: Mohyliv-Podilskyi district: Serebria - on the lawns on the roadside, in several places, 02.08.2019 !!, f.r. Shargorod: center, on the lawns, wildly, 18.06.2010 !!, f.r. Zhytomyr region: Popilnya district: Popilnya - the northern vicinities, near the forestry homestead, on the sandy roadside, some big curtains, 06.16.2019 !! (KWHA); Kornynske - on the side of the road, 16.06.2019 !! f.r. Kyiv: M.M. Gryshko NBG NAS of Ukraine: often in open sandy areas in the central part of the garden (Shynder, 2019 b); near the Druzhby Narodiv metro station - dry slopes of the avenue, 2014 !!, f.r.; Holosiivskyi district: along Holosiivskyi avenue, on the city flowerbeds and the lawns, wildly, 2012 !!, f.r. Kyiv region: Bila Tserkva: Arboretum Oleksandriya - on nurseries and flowerbeds like a weed, sub S. hispanicum (Doyko \& Katrevych, 2015); in the same place, on the nurseries and lawns, wildly and like a weed, 22.05.2019 !!, f.r. Obukhiv district: Pidgirtsi - on the side of the road, a few curtains, 2.09.2018 !!, f.r. Stavishchensky district: Stavishche - the central park, on the roadside, synanthropic, 14.08.2018 !!, f.r. Cherkasy region: Kaniv: in the center, on the lawns and roadsides, often, 10.08.2019, O.I. Shynder, Yu.M. Negrash f.r. Cherkasy: from B. Khmelnitsky square through the Druzhby narodiv street to the Dnieper, absently on the lawns and roadsides, 13.08.2018 !! f.r. Cherkasy district: Basy - the western vicinities, the quarter number 249 of the Tasminsky forestry, on the sandy roadside of the glade in the pine forest, a few curtains, 10.08.2018, O.I. Shynder, G.A. Chorna (KWHA).

STEPPE. Zaporizhia region: Berdyansk: Daleka Kosa, $100 \mathrm{~m}$ from the shop "Shturval", on the sand, absently, 09.2018, O.F. Levon, ph.m.; Berdyansk, in the port, on the ruderal sand section, 09.2018, O.F. Levon, ph.m.; Odesa region: Odesa: botanical garden, old territory, sporadically in the arboretum, wildly, 21.09.2017 !! f.r.

EASTERN CARPATHIAN FOOTHILLS. Ivano-Frankivsk region: Ivano-Frankivsk: roadside of dirt road, 48.893472, 24.782833, 2018, I. Klishch, Image ID \# 63962 (UkrBIN, 2020). Tysmenytsya district: Urochysche Mokrets, 48.853258, 24.799695, 2017, I. Klishch, Image ID \# 39185 (UkrBIN, 2020). Lviv region: Truskavets: the eastern vicinities, between railway tracks, $300 \mathrm{~m}$ after the crossing, $49.28458^{\circ}, 23.52213^{\circ}, 5.10 .2019$ !! f.r., the same, Image ID \# 141118 (UkrBIN, 2020) (Fig. 5); Truskavets: on the perimeter of the parking behind the market, abundantly, 12.10.2019!! (KWHA). 


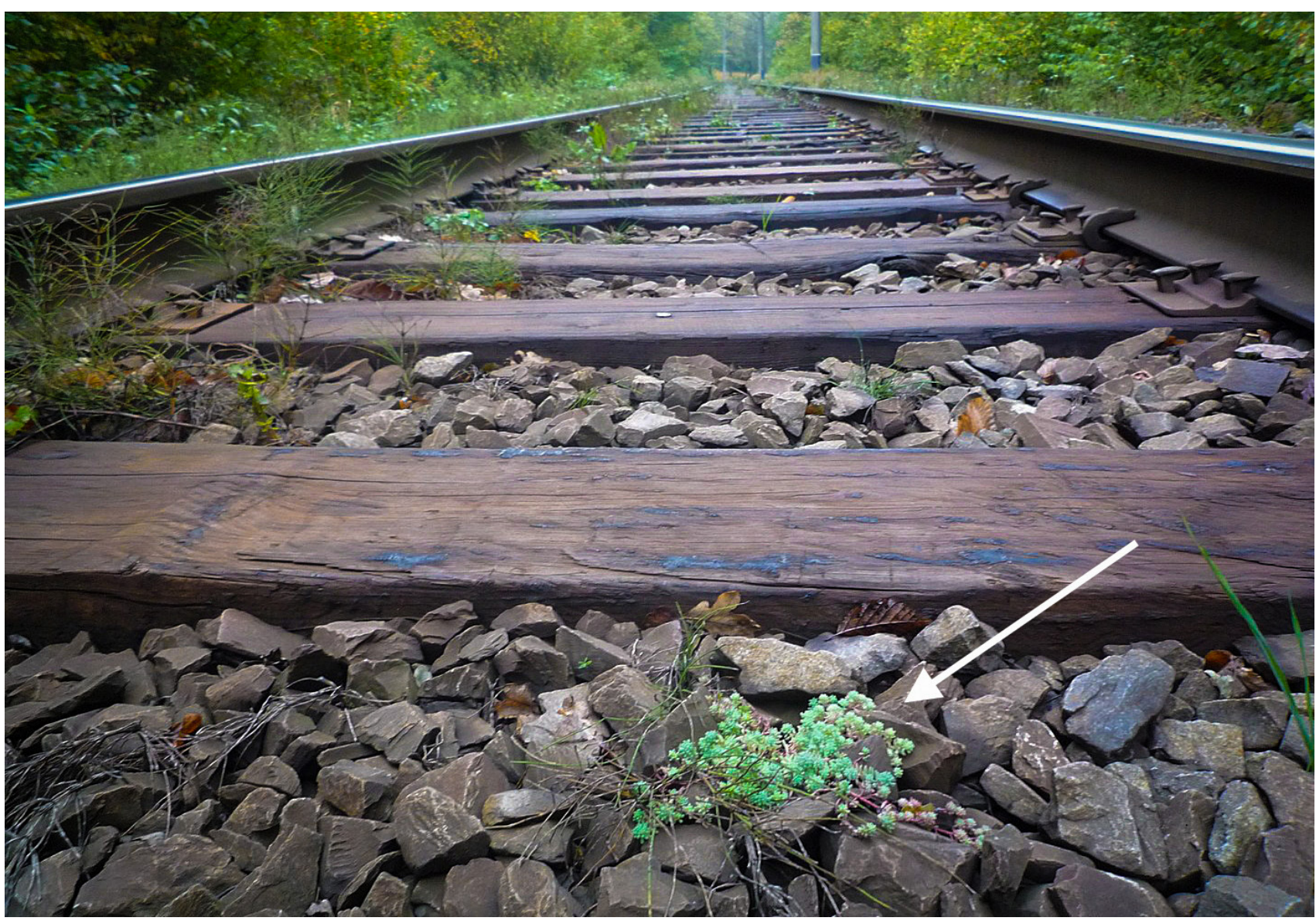

Figure 5. Sedum pallidum on a railway track in the vicinity of Truskavets, Lviv region.

\title{
Sedum pallidum (Crassulaceae) - чужорідний вид флори рівнинної частини України
}

\author{
О.І. Шиндер *, Ю.М. Неграш
}

Національний ботанічний сад імені М.М. Гришка НАН України, вул. Тімірязєвська, 1, м. Київ, 01014, Україна; * shinderoleksandr@gmail.com

Мета - з'ясувати сучасне поширення Sedum pallidum в Україні, проаналізувати його стан у складі чужорідної флори України.

Матеріал та методи. Дослідження проведено у 2008-2019 рр. на території рівнинної частини України та у Гірському Криму. Проаналізовані літературні відомості, фонди кількох вітчизняних гербаріїв та інші джерела. Особливу увагу приділяли відділенню спонтанних місцезростань S. pallidum від культурних.

Результати. S. pallidum - субеквксинський вид, ареал якого охоплює Гірський Крим. Широко культивується по всій Україні і схильний до натуралізації, розмножуючись вегетативно і генеративно. Загалом зафіксовано біля 30 спонтанних місцезнаходжень S. pallidum, переважно у Середньому Придніпров'ї і Західній Україні. Сприятливою еконішою для S. pallidum $\epsilon$ міські газони та узбіччя доріг на легких субстратах.

Висновки. S. pallidum - чужорідна рослина у флорі рівнинної частини України, ергазіофіт за походженням. Встановлено, що в умовах культури у Лісостепу S. pallidum - це трав'яний багаторічник, а виділені у його складі дві раси (var. pallidum i var. bithynicum) імовірно є екадами і не 
мають систематичного значення. В умовах культури S. pallidum успішно розмножується вегетативно і генеративно, що сприяє його натуралізації. S. pallidum часто плутають із іншими видами роду, що не сприяло його вивченню у складі адвентивних флор. Запропоновано ключ для ідентифікації S. pallidum. Потенційний вторинний синантропний ареал цього виду охоплює всю країну за винятком високогір'я Карпат.

Ключові слова: Sedum pallidum, чужорідний вид, флора, нові локалітети, Україна 